\title{
ANTIBODY TO HUMAN T-LYMPHOTROPIC VIRUS IN A PATIENT WITH GUILLAIN-BARRÉ SYNDROME (CASE REPORT)
}

\author{
C.M. NAKAUCHI (1), A.C. LINHARES (1), M.L.C. GOMES (1), K. MARUYAMA (2), L.I. KANZAKI (3) \& V.N. \\ AZEVEDO (3).
}

\begin{abstract}
SUMMARY
Serum sample obtained from a male, 12 year old paticnt suffering from Guillain-Barré syndrome (GBS) was positive for human T-lymphotropic virus (HTLV-I) antibody by the enzyme-linked immunosorbent assay (ELISA) and the Western Blot analysis (WB). Attempts to isolate enteroviruses (including poliovirus) from faecal material in both tissue culture and suckling mice were unsuccessful; in addition, acute and convalescent paired serum samples did not show any evidence of recent poliovirus infection when tested against the three serotypes. Specific tests for detection of Epstein-Barr virus infection were not performed; however, the Paul-Bunnel test yielded negative results. ELISA for detection of anti-cytomegalovirus $\operatorname{IgM}$ was also negative. The concomitant occurrence of either adult $\mathrm{T}$ cell leukemia (ATL) or lymphoma was not recorded in this case.
\end{abstract}

KEY WORDS: HTLV-I; Antibody; Guillain-Barré syndrome

\section{INTRODUCTION}

Distinct clinical entities have been associated with human T-lymphotropic virus type I (HTLV-I) infection in humans since the pioneer findings of POIESZ et al ${ }^{9}$. HTLV-I is widely recognized as the causative agent of specific forms of malignancies such as adult T cell leukemia/lymphoma (ATL) ${ }^{12}$. In addition, this retrovirus has been implicated in the actiology of neurological disorders, which are mainly characterized by a chronic myclopathy condition: tropical spastic paraparesis (TSP) in endemic areas of the Caribbean ${ }^{10}$ and HTLV-I associated myelopathy (HAM) in temperate regions ${ }^{8}$. It has also been suggested that HTLV-I infection is linked to neuropsychiatric disease ${ }^{5}$.

Studies dealing with the possible relationship between HTLV-I infection and neurological disorders have, to date, not been performed in Brazil. It has been largely demonstrated, however, that HTLV-I and/or a human retrovirus antigenically related to HTLV-I circulates among both urban and isolated populations. MERINO $\mathrm{et} \mathrm{al}^{6}$. have reported a $13.7 \%$ seropositivity in Amazonian Indians inhabiting the Yanomani village. ANDRADASERPA et $\mathrm{al}^{1}$. have recorded scroprevalence rates of $0.84 \%$ and $3.72 \%$ in Amazonian Indians and cancer patients, respectively. More recently, NAKAUCHI et al? . have found the prevalence of HTLV-I antibody in two Indian communities and among patients with cancer of different organs living in the Amazon region.

This report presents results from a preliminary investigation on the possible involvement of HTLV-I infection in the pathogenesis of GB syndrome in Northern Brazil.

\section{PATIENT AND METHODS}

Our patient (A.F.M.) was a 12 year old boy

(1) Seção de Vírus do Instituto Evandro Chagas, Fundação Nacional de Saúde. Belém, Pará, Brazil.

(2) Department of Pathology. Chiba Cancer Center Research Institute, Chiba, Japan.

(3) Disciplina de Virologia, Departamento de Patologia, Universidade Federal do Pará. Belém, Pará, Brazil.

Address for correspondence: Dr. A.C. Linhares, Seção de Vírus, Instituto Evandro Chagas. Av. Almirante Barroso, 492. CEP66.050 - Belém, Pará, Brasil. 
NAKAUCHI, C.M.; LINHARES, A.C.; GOMES, M.L.C.; MARUYAMA, K.; KANZAKI, L.I. \& AZEVEDO, V.N. - Antibody to human T-lymphotropic virus in a patient with Guillain-Barré syndrome(Case report). Rev. Inst. Med. trop. S. Paulo, 33 (4): 329-331, 1991.

living in Bragança, rural area of Pará state, at 194 $\mathrm{km}$ to the North of Belém. The clinical picture mainly involved progressive motor weakness of both limbs and arms and diminished reflexes. Tetraparesia and facial palsy were the more prominent neurological manifestations; the latter began suddenly and was flaccid and asymmetrical. Neither sensory change nor nerve sensitivity to pressure could be detected. Low grade fever, myalgia and headache were recorded during the 10 days preceding the onset of neurological symptoms. Faecal samples, as well as sorum sample were collected during the acute phase of disease; another serum specimen was obtained one month later. The cerebro spinal fluid was not available for laboratory examination. The patient was reported to have recovered spontaneously within few weeks with minor residual effects.

ELISA was carried out essentially as recommended by BURRELLS \& DAWSON ${ }^{2}$ and virus preparation was obtained from culture fluid harvested from Lma-66 cell line (MARUYAMA et al., 1982) ${ }^{3}$. The WB was performed as previously described ${ }^{4}$, using monoclonal antibodies to HTLVI p 19 (obtained from CPI, Buffalo, N.Y.) and to $\mathrm{p}$ 24 (obtained from Du Pont, Billerica, MA).

By using standard serological procedures, paired serum samples were tested for the presence of antibody for poliovirus. In addition, faecal sample was inoculated onto confluent monolayer culture of Vero and HEp 2 cells and, intra-cerebrally, into suckling mice. These isolation systems were observed during a period of two weeks for signs of viral infection. The Paul-Bunnel reaction and ELISA for IgM (kit supplied by Organon Tekinica, Rua João Alfredo, 403, Sto. Amaro, CEP 04747, São Paulo, SP) were used for the diagnosis of EBV and cytomegalovirus (CMV) infections, respectively.

\section{RESULTS}

Both acute and convalescent serum samples yielded positive results in both ELISA (O.D. = 1.32) and WB. By using the latter technique, specific reaction with viral peptide p 19 was detected, as demonstrated in Fig. 1. All attempts to isolate viruses from faecal sample in either tissue culture (HEp 2 and Vero cells) and suckling mice were unsuccessful. In addition, the paired serum samples failed to neutralize poliovirus serotypes.
Negative results were obtained by using both the Paul-Bunnel test and ELISA for detection of anti cytomegalovirus IgM.

\section{DISCUSSION}

The detection of anti-HTLV-I antibody in serum sample from a patient suffering from GuillainBarré syndrome, associated with a lack of any other possible infectious aetiological agents - in particular poliovirus - led us to consider a possible association between the retrovirus infection and the neurological disorder. The detection of antibody to HTLV-I was based on both ELISA and WB. In the latter technique, specific reaction was noted only with the $p 19$ gag peptide of HTLV-I, suggesting a possible involvement of a human retrovirus carrying a protein shared in common with p 19 of HTLV-I. Previous studies carried out by NAKAUCHI et $\mathrm{a}^{7}$. raised the possibility that a retrovirus antigenically related to HTLV-I circulates among Amazonian populations.

Unlike previously described HTLV-I associated neurological syndromes, namely TSP and HAM, our patient had flaccid facial palsy and tetraparesia, apart from other symptoms which met the criteria for Guillain-Barré syndrome. The detection of HTLV-I antibody in cerebrospinal fluid was unfortunately not available from our patient and therefore neither examination for "albuminocytologic dissociation" nor for HTLV-I antibody in cerebrospinal fluid were carried out.

In spite of our failure to demonstrate recent enterovirus infection, we cannot rule out the possibility of other pathogens in the aetiology of the present Guillain-Barré case. Although non-specific, the negative Paul-Bunnel test may constitute an evidence that EBV was not associated with the present Guillain-Barré syndrome. In addition, recent CMV infection can be ruled out on the basis of negative ELISA for specific IgM. We should add that, at least on clinical grounds, preceding viral or mycoplasma infections were not detected. In addition, conditions such as lymphoid neoplastic or autoimmune connective tissue diseases were not found in the patient. The seropositivity for $p 19$ of HTLV-I leads us to speculate on a possible involvement of a retrovirus that is partially related to HTLV-I in the pathogenesis of this neurological syndrome. In order to confirm the proposed relationship between HTLV-I infection and Guillain- 


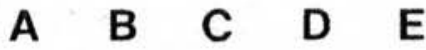

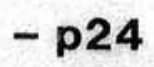

$-p 19$

- p15

Western blots of HTLV-I with different sera.
A : Serum (1:10) from a Brazilian with

Guillain-Barré syndrome.

B : Serum (1:100) from a Japanese with ATL.

C : Monoclonal antibody $(1: 20,000)$ to HTLV-I-p 15.

D : Monoclonal antibody (1:500) to HTLV-I-p19.

E : Monoclonal antibody $(1: 5,000)$ to HTLV-I-p24. 
NAKAUCHI, C.M.; LINHARES, A.C.; GOMES, M.L.C.; MARUYAMA, K.; KANZAKI, L.I. \& AZEVEDO, V.N. - Antibody to human T-lymphotropic virus in a patient with Guillain-Barré syndrome(Case report). Rev. Inst. Med. trop. S. Paulo, 33 (4): 329-331, 1991.

Barré syndrome, routine examinations should be performed with both serum samples and cercbrospinal fluids collected from patients suffering from this neurological disorder.

\section{RESUMO}

\section{Anticorpo para o vírus linfotrópico humano $T$ em um paciente com a síndrome de Guillain-Barré}

Amostra de soro obtida de paciente com a síndrome de Guillain-Barré revelou-se positiva quanto à presença de anticorpos para o vírus linfotrópico humano $\mathrm{T}$ (HTLV-I) pelo método imuno-enzimático (ELISA) e a análise por "Westem-Blot". Resultaram negativos os testes visando à detecção de enterovírus (incluindo poliovírus) a partir de material fecal, tanto em cultura de tecidos como em camundongos recém-nascidos; exames com amostras de soro aguda e convalescente não exibiram qualquer evidência de infecção recente pelos três tipos de poliovírus. O teste de PaulBunnel, assim como o "ELISA" para a detecção de IgM anti-citomegalovirus resultaram negativos. Não foi registrada, no presente caso, quer a leucemia adulta de células $\mathrm{T}$, quer linfomas.

\section{ACKNOWLEDGEMENTS}

The technical ddvice provided by Ms. Cereja Kazuko Nakauchi, Mrs. Laura Nakauchi and Ms. Euda Galiza is gratefully acknowledged.

\section{REFERENCES}

1. ANDRADA-SERPA, M.J.; DOBBIN, J.A.; GOMES, P.; LINHARES, D.; AZEVEDO, J.G.; HENDRICKS, J.; CLAYDEN, S.A.; RUMJANEK, V.M. \& TEDDER, R.S. - Incidence of retroviruses in some Brazilian groups. Immunol. Lett., 18: 15-18, 1988.

2. BURRELLS, C. \& DAWSON, Mc L. - ELISA methodology: Variations in technical procedures. In: WARDLEY, R.C., \& CROWTHER, J.R. - The ELISA: Enzymelinked immunosorbent assay in veterinary research and diagnosis. The Hague, Maninus Nijhoff, 1982. p. 19.

3. MARUYAMA, K.; KAWAMURA, K.; MIYAUCHI, M.;
MOCHIZUKI, S.; FUKUSHIMA, T.; TAKAGI, T. \& OGURO, M. - Establishment of cell lines producing both type $C$ vinus and herpestype virus and derived from adult T - cell leukemia. Proc. Jap. Cancer Ass, 41: 342, 1982.

4. MARUYAMA, K.;MIYAUCHI, M.; FUKUSHIMA, T; MOCHIZUKI, S.; KOSIIIKAWA, N.; KAWAMURA, K.; TAMAYAMA, C.; NAKANO, M.; ODO, A. \& IHA, S. - Antigenic variations of retrovinus in Japanese cancer paticnts. Leukemia, 3: 277-281, 1989.

5. MATTOCK, C. \& PARKER, N.E. - HTLV-I infection and schizophrenia. Lancet, 2: 945, 1985.

6. MERINO, F.; ROBERT-GUROFF, M.; CLARK, J.; BIONDO-BRACHO, M.; BLATNNER, W.A. \& GALLO, R.C. - Natural antibodies to human T - cell leukemia/ lymphoma virus in healthy Venezuelan populations. Int. J. Cancer, 34: 501-506, 1984.

7. NAKAUCHI, C.M.; LINHARES, A.C.; MARUYAMA, K.; KANZAKI, L.I.; MACEDO, J.E.; AZEVEDO, V.N. \& CASSEB, J.S.R. - Prevalence of human T - cell leukemia - virus - I (HTLV-I) antibody among populations living in the Amazon region of Brazil. Mem. Inst. Oswaldo Cruz, 85: 29-33, 1990.

8. OSAME, M.; USUKU, K.; IZUMO, S.; IJICHI, N.; AMITANI, H.; IGATA, A.; MATSUMOTO, M. \& TARA, M. - HTLV-I associated myelopathy, a new clinical entily. Lancet, 1: 1031-1032, 1986.

9. POIESZ, B.J.; RUSCETTI, F.N.; GAZDAR, A.F.; BUNN, P.A.; MINNA, J.D. \& GALLO, R.C. - Detection and isolation of type $C$ retrovinus particles from fresh and cultured lymphocytes of a patient with cutaneous $\mathrm{T}$ - cell lymphoma. Proc. nat. Acad. Sci. (Wash.), 77: 7415$7419,1980$.

10. ROMAN, G.C.; SPENCER, P.S.; SCHOENBERG, B.S.; MADDEN, D.; SEVER, J.; IHUGON, J. \& LUDOPH, A. - Tropical spastic paraparesis: HTLV-I antibodies in patients from the Seychelles. New Engl. J. Med., 316: 51, 1987.

11. SCHOOLEY, R.T. \& DOLN, R. - Epstein-Barr virus (infectious mononucleosis). In: MANDELL, G.L., DOUGLAS JR., R.G. \& BENNETT, J.E. ed. Principles and practice of infectious diseases. New York, John Wiley \& Sons, 1979. p. 1324-1341.

12. YOSHIDA, M.; MIYOSHI, I. \& HINUMA, Y. - Isolation and characterization of retrovinus from cell lines of human adult $T$ - cell leukemia and its implication in the disease. Proc. nat. Acad. Sci. (Wash.), 79: 2031-2035, 1982.

Recebido para publicação em $07 / 1$ 1/1990 Aceito para publicação em 15/01/1991 